\title{
ANALISIS PENGARUH TINGKAT LIKUIDITAS TERHADAP PROFITABILITAS PADA PT MEDIA NUSANTARA CITRA Tbk PERIODE 2009-2017
}

\author{
Ikhwanuddin, Ahmad Iqbal Tanjung, Ica Yan Sari Siregar \\ Institut Agama Islam Negeri Padangsidimpuan \\ Jl. T. Rizal Nurdin Km.4,5 Kelurahan Sihitang \\ Email: zulaikmatondang@yahoo.com
}

\begin{abstract}
ABSTRAK
Latar belakang masalah dalam penelitian ini adalah naik turunnya antara tingkat likuiditas terhadap profitabilitas yang menunjukkan bahwa tidak setiap kejadian sesuai dengan teori yang ada. Rumusan masalah dalam penelitian ini adalah "Apakah TerdapatPengaruh Tingkat LikuiditasTerhadapProfitabilitasPada PT Media Nusantara Citra Tbk periode 20092017. Tujuan penelitian ini adalah untuk mengetahui pengaruh tingkat likuiditas terhadap profitabilitas pada PT Media Nusantara Citra Tbk periode 2009-2017.

Pembahasan penelitian ini berkaitan dengan bidang ilmu akuntansi dengan topik pembahasan adalah analisis pengaruh tingkat likuiditas terhadap profitabilitas pada laporan keuangan PT Media Nusantara Citra Tbk periode 2009-2017. Sehubungan dengan itu, pendekatan yang dilakukan adalah teori-teori yang berkaitan dengan rasio likuiditas dan rasio profitabilitas sebagai aspek-aspek atau bagian-bagian tertentu dari keilmuan tersebut.

Jenis penelitian ini adalah penelitian kuantitatif analisis deskriptif, sumber data adalah data sekunder dengan bentuk laporan keuangan dari PT Media Nusantara Citra Tbk, sampel yang digunakan berjumlah 35 data sampel. Teknik pengumpulan data adalah laporan keuangan publikasi triwulan yang dipublikasikan PT Media Nusantara Citra Tbk periode 2009-2017. Data diperoleh melalui situs resmi Bursa Efek Indonesia (BEI), yaitu www.idx.co.id. Kemudian diolah dengan bantuan SPSS Versi 23. Teknik analisis data dengan metode regresi sederhana, analisis statistik deskriptif, uji normalitas dan uji t.

Hasil penelitian ini menunjukkan secara parsial (uji-t) tingkat likuiditas tidak terdapat pengaruh secara signifikan terhadap profitabilitas yang dibuktikan dengan nilai $t_{\text {hitung }}(0,735<$

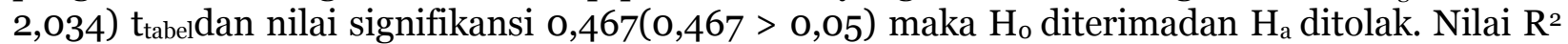
sebesar 0,016 artinya persentase sumbangan pengaruh varibel $\mathrm{X}$ (tingkat likuiditas) terhadap variabel Y (profitabilitas) sebesar 1,6 persen, sedangkan 98,4 persen dipengaruhi oleh variabel lain yang tidak dimasukkan dalam penelitian ini.
\end{abstract}

Kata Kunci : Tingkat Likuiditas dan Profitabilitas 


\section{PENDAHULUAN}

Perusahaan adalah sebuah organisasi yang beroperasi dengan tujuan untuk meningkatkan kemampuan suatu perusahaan dalam memenuhi kewajibannya dan dapat menghasilkan keuntungan. Sebagaimana tujuan utama perusahaan pada umumnya, yaitu memperoleh laba atau keuntungan yang maksimal.

Dalam praktik, tidak sedikit dijumpai perusahaan yang kerap kali mengalami kesulitan finansial sehingga tidak mampu mendanai kegiatan operasionalnya maupun dalam melakukan pembayaran utang.

PT Media Nusantara Citra Tbk atau MNCN merupakan perusahaan media terbesar dan paling terintegrasi di Indonesia. MNC telah mengoperasikan 4 dari 11 stasiun FreetoAir (FTA) TV dan memiliki bisnis inti dalam memproduksi dan mendistribusikan konten konten televisi. Perseroan yang didirikan pada tanggal 17 Juni 1997 merupakan perusahaan publik yang sahamnya telah tercatat dalam Bursa Efek Indonesia (BEI) sejak tanggal 22 Juni 2007, dengan kode saham 'MNCN.

Rasio likuiditas dapat diukur dengan menggunakan beberapa rasio seperti rasio lancar (current ratio), rasio cepat (quick ratio) dan rasio kas (cash ratio). Sedangkan rasio profitabilitas dapat diukur dengan menggunakan beberapa rasio seperti profit margin (profit margin on sales), return on invesment (ROI), return on equity (ROE) dan laba per lembar saham biasa (earning per share of common stock).

Setelah mengukur rasio profitabilitas, penting bagi suatu perusahaan mengukur rasio yang mempengaruhi profitabilitas tersebut, diantaranya rasio likuiditas. Konsep likuiditas diartikan sebagai pengujian kecukupan dana atau kemampuan perusahaan tersebut dalam memenuhi kewajiban yang harus segera dibayar, umumnya kurang dari satu tahun. Kemampuan itu dapat diwujudkan bila jumlah harta lancar lebih besar dari pada utang lancar. ${ }^{1}$

Untuk mengukur tingkat keuntungan suatu perusahaan, digunakan rasio keuntungan atau rasio profitabilitas. Rasio profitabilitas adalah rasio yang digunakan untuk menilai kemampuan perusahaan dalam mencari keuntungan. Rasio ini juga memberikan ukuran tingkat efektivitas manajemen suatu perusahaan. ${ }^{2}$ Kemampuan memperoleh laba selama periode tertentu akan mengorbankan likuiditas.

\footnotetext{
${ }^{1}$ Dewi Utari, dkk. Manajemen Keuangan: Edisi Revisi (Jakarta: Mitra Wacana Media, 2014), hlm. 60.

${ }^{2}$ Kasmir, Op. Cit., hlm. 196.
} 
Adapun fenomena-fenomena yang terjadi dalam penelitian ini selain terjadinya naik turun dari tingkat likuiditas dan profitabilitas terdapat juga fenomena lain. Kasmir mengatakan "semakin tinggi rasio lancar maka semakin baik karena banyaknya jumlah aktiva lancar yang akan digunakan sebagai modal kerja perusahaan dalam memperoleh keuntungan yang tinggi." 3 Tetapi hal ini tidak selalu seperti yang terjadi pada PT Media Nusantara Citra Tbk yang dimana apabila rasio likuiditas meningkat maka profitabilitas yang dihadapi akan menurun.

Berdasarkan uraian dan permasalahan diatas maka peneliti tertarik untuk melakukan penelitian tentang analisis pengaruh tingkat likuiditas terhadap profitabilitas. Penelitian dilakukan akan dirangkumkan dalam judul "Analisis Pengaruh Tingkat Likuiditas Terhadap Profitabilitas Pada PT Media Nusantara Citra Tbk Periode 2009-2017"

\section{TINJAUAN TEORITIK}

\section{Definisi Profitabilitas}

Profitabilitas adalah rasio yang mengukur efektifivitas manajemen secara keseluruhan yang ditujukan oleh besar kecilnya tingkat keuntungan yang diperoleh dalam hubungannya dengan penjualan maupun investasi. Semakin baik rasio profitabilitas maka semakin baik menggambarkan kemampuan tingginya perolehan keuntungan perusahaan. ${ }^{4}$ Profitabilitas merupakan rasio untuk menilai kemampuan perusahaan dalam mencari keuntungan. Rasio ini juga memberikan ukuran tingkat efektivitas manajemen suatu perusahaan. Hasil pengukuran tersebut dapat dijadikan alat evaluasi kinerja manajemen selama ini, apakah mereka telah bekerja secara efektif atau tidak. Pengetahuan tentang kondisi dan posisi profitabilitas perusahaan dapat diketahui secara sempurna. Salah satunya dengan cara mengetahui tingkat

\footnotetext{
${ }^{3}$ Kasmir, Analisis Laporan Keuangan, (Jakarta: Rajawali Pers, 2013), hlm. 251.

${ }^{4}$ Irham Fahmi, Analisis Investasi Dalam Persepektif Ekonomi Dan Politik (Bandung: Penerbit Refika Aditama, 2011), hlm. 68.
} 
pengembalian investasi (Return On Investment) yang diperoleh perusahaan yang bersangkutan. 5

Analisa ROI dalam analisa keuangan mempunyai arti yang sangat penting sebagai salah satu teknik analisa keuangan yang bersifat menyeluruh (komprehensif). Analisa ROI ini sudah merupakan teknik analisa yang lazim digunakan oleh pimpinan perusahaan untuk mengukur efektivitas dari keseluruhan operasi perusahaan.

ROI itu sendiri adalah salah satu bentuk dari rasio profitabilitas yang dimaksudkan untuk dapat mengukur kemampuan perusahaan dengan keseluruhan dana yang ditanamkan dalam aktiva yang digunakan untuk operasinya perusahaan untuk menghasilkan keuntungan. Dengan demikian, rasio ini menghubungkan keuntungan yang diperoleh dari operasinya perusahaan (net operating income) dengan jumlah investasi atau aktiva yang digunakan untuk menghasilkan keuntungan operasi tersebut (net operating assets). ${ }^{6}$

Adapun faktor-faktor yang mempengaruhi besarnya ROI adalah 1) Turnover dari operating assets (tingkat perputaran aktiva yang digunakan untuk operasi), melihat seberapa jauh aktiva ini telah dipergunakan di dalam kegiatan perusahaan dalam suatu periode tertentu.2) Profit margin, yaitu besarnya keuntungan operasi yang dinyatakan dalam persentase dan jumlah penjualan bersih. Profit margin ini mengukur tingkat keuntungan yang dapat dicapai oleh perusahaan yang dihubungkan dengan penjualannya.

Besarnya ROI akan berubah kalau ada perubahan net profit margin atau assets turnover, baik masing-masing atau kedua-duanya. Dengan demikian maka pimpinan perusahaan dapat menggunakan salah satu atau kedua-duanya dalam rangka usaha untuk memperbesar ROI. Usaha mempertinggi ROI dengan memperbesar profit margin adalah bersangkutan dengan usaha untuk mempertinggi efisiensi di sektor produksi, penjualan dan administrasi. Usaha mempertinggi ROI dengan memperbesar assets turn over adalah kebijaksanaan investasi dana dalam berbagai aktiva, baik aktiva lancar maupun aktiva tetap. 7

${ }^{5}$ Hasibuan, Abdul Nasser, Effects of Auditor Quality on Market-besed and Accounting-based Financial Statement Quality and Its Impacts on Economic Consequences (A Case Indonesian Capital Market), Internasional Journal of Economic Research No.14 (2017).

${ }^{6}$ S.Munawir, Analisa Laporan Keuangan(Yogyakarta: Liberty Yogyakarta, 2007),hlm.89.

${ }^{7}$ Ibid., hlm. 89. 


\section{Definisi Likuiditas}

Likuiditas merupakan kemampuan perusahaan untuk memenuhi kewajiban finansial yang berjangka pendek tepat pada waktunya. ${ }^{8}$ Rasio Likuiditas merupakan rasio yang digunakan dalam mengukur seberapa likuid suatu perusahaan. Caranya adalah dengan membandingkan seluruh komponen yang ada di aktiva lancar dengan komponen di passiva lancar (utang jangka pendek). ${ }^{9}$ Semakin tinggi current ratio ini berarti semakin besar kemampuan perusahaan untuk memenuhi kewajiban finansial jangka pendek. Aktiva lancar yang dimaksud termasuk kas, piutang, surat berharga, dan persediaan. ${ }^{10}$ Menurut Syafrida Hani, menyatakan bahwa "faktor-faktor yang dapat mempengaruhi likuiditas adalah unsur pembentuk likuiditas itu sendiri yakni bagian dari aktiva lancar dan kewajiban lancar, termasuk perputaran kas, arus kas operasi, ukuran perusahaan, kesempatan bertumbuh, keragaman arus kas operasi dan rasio utang atau struktur utang.”

Rasio likuiditas adalah rasio yang berhubungan dengan masalah kemampuan suatu perusahaan untuk memenuhi kewajiban finansialnya yang segera harus dipenuhi.11 Dari pengertian yang telah diuraikan diatas dapat diambil kesimpulan bahwa rasio likuiditas merupakan gambaran kemampuan perusahaan dalam memenuhi kewajiban finansialnya (utang) jangka pendek pada saat sudah jatuh tempo. Analisis rasio likuiditas merupakan teknik analisis yang lazim digunakan untuk mengukur kemampuan likuiditas jangka pendek perusahaan dengan melihat besarnya aktiva lancar relatif terhadap hutang lancarnya. ${ }^{12}$

Likuiditas perusahaan, menunjukkan kemampuan untuk membayar kewajiban finansial jangka pendek tepat pada waktunya Likuiditas perusahaan ditunjukkan oleh besar kecilnya aktiva lancar yaitu aktiva yang mudah untuk diubah menjadi kas yang meliputi kas, surat berharga, piutang, persediaan. Dengan menggunakan laporan keuangan yang terdiri atas neraca, laporan rugi laba dan laporan perubahan modal. Semakin tinggi current ratio ini berarti semakin besar kemampuan perusahaan untuk memenuhi kewajiban finansial jangka pendek.13

Perusahaan yang kekuatan membayarnya besar sehingga mampu memenuhi segala kewajiban jangka pendeknya dikatakan bahwa perusahaan itu likuid. Masalah likuiditas adalah berhubungan dengan masalah kemampuan perusahaan untuk memenuhi kewajiban finansialnya yang segera harus dipenuhi. Ada dua hasil penilaian terhadap pengukuran rasio

${ }^{8}$ Lukas Setia Atmajaya, Manajemen Keuangan, Edisi Revisi (Yogyakarta:Andi, 2003), hlm. 415.

${ }^{9}$ Kasmir \& Jakpar, Studi Kelayakan Bisnis, edisi 2 cetakan keenam (Jakarta: Kencana, 2009), hlm. 122.

${ }^{10}$ S. Munawir, Analisa Laporan Keuangan (Yogyakarta: Liberty Yogyakarta, 2007), hlm. 72.

${ }^{11}$ Bambang Riyanto, Dasar-dasar Pembelanjaan Perusahaan (Yogyakarta:Penerbit GPFE, 2008), hlm. 25.

${ }^{12}$ Muda, Iskandar dan Abdul Nasser Hasibuan, Public Discovery of The Concept of Money with Value of Time Emerald Reach Proceeding Series (Proceeding of MICoMS 2017), Vol 1 pp.255-261

${ }^{13}$ R. Agus Sartono,Manajemen Keuangan Teori dan Aplikasi Edisi 4 (Yogyakarta: BPFE, 2010), hlm. 116. 
likuiditas, yaitu apabila perusahaan mampu memenuhi kewajibannya, dikatakan perusahaan tersebut dalam keadaan likuid. Sebaliknya, apabila perusahaan tidak mampu memenuhi kewajiban tersebut, dikatakan perusahaan dalam keadaan ilikuid.

\section{Hubungan Rasio Likuiditas dan Profitabilitas}

Likuiditas merupakan perbandingan antara aktiva lancar dengan utang lancar dan profitabilitas itu merupakan rasio yang digunakan untuk mengukur kemampuan perusahaan dalam menghasilkan laba. Jadi, antara likuiditas dan profitabilitas mempunyai hubungan yang dimana jika perusahaan tidak memilki banyak kewajiban yang akan segera dibayar maka perusahaan tersebut akan menghasilkan laba dan mampu meningkatkan kesejahteraan perusahaan tersebut.

\section{METODOLOGI PENELITIAN}

Penelitian ini dilakukan pada PT Media Nusantara Citra Tbk Periode 2009-2017 yang terdaftar di Indeks Saham Syariah Indonesia. Adapun waktu penelitian ini dilakukan pada bulan September 2017 sampai dengan Juli 2018, yang dimulai dari penyusunan penelitian sampai dengan penulisan laporan penelitian. Dalam penelitian ini peneliti menggunakan metode kuantitatif. Dalam penelitian ini peneliti menggunakan dua variabel yaitu variabel bebas dan variabel terikat, yang menjadi variabel bebasnya yaitu tingkat likuiditas (X) dan variabel terikatnya yaitu profitabilitas (Y). Populasi dalam penelitian ini adalah laporan keuangan PT Media Nusantara Citra Tbk atau perusahaan jasa yang terdaftar di Indeks Saham Syariah Indonesia dari tahun 2009-2017 per triwulan. Sampel dari penelitian ini adalah data total tingkat likuiditas dan profitabilitas dari PT Media Nusantara Citra Tbk dari tahun 2009 sampai 2017 dengan jumlah sampel sebanyak 35 data laporan keuangan.

Teknik Pengumpulan data dalam penelitian ini adalah dengan menggunakan dokumentasi dan studi kepustakaan.. ${ }^{14}$ Instrumen pengumpulan data yang diperoleh dari buku-buku, jurnal dan sumber bacaan lain yang berkaitan dengan penelitian ini. Teknik analisis data dalam penelitian ini menggunakan Deskriptif Statistik, Uji Normalitas, Uji Analisis Regresi Linear Sederhana, Uji HipotesiS, Uji Koefisien Determinasi R², Uji Parsial (Uji t).

\footnotetext{
${ }^{14}$ Sumadi Suryabrata, Metodologi Penelitian (Jakarta: PT. RajaGrafindo Persada, 1998), hlm. 93.
} 


\section{HASIL PENELITIAN}

Secara parsial hasil penelitian ini menyatakan bahwa variabel tingkat likuiditas tidak berpengaruh terhadap profitabilitas. Disini dapat dilihat bahwa teori tidak selamanya sesuai dengan praktek yang dijalankan oleh PT Media Nusantara Citra Tbk. Alasannya yaitu profitabilitas yang dihasilkan oleh PT Media Nusantara Citra Tbk ternyata tidak mencukupi untuk kewajiban lancarnya. Kenyataannya adalah bahwa ada faktor-faktor lain yang justru mempengaruhi profitabilitas yang menggunakan rasio ROI di PT Media Nusantara Citra Tbk.

Hasil analisis mengenai analisis pengaruh tingkat likuiditas terhadap profitabilitas pada PT Media Nusantara Citra Tbk periode 2009-2017. Dalam penelitian ini menunjukkan hasil yang tidak signifikan. Dari hasil uji deskriptif dapat dilihat bahwa variabel jumlah data $(\mathrm{N})$ adalah 35, untuk nilai minimum tingkat likuiditas sebesar 1,37 kali tingkat likuiditas, nilai minimum dari profitabilitas sebesar o,81 persen. Nilai maximum tingkat likuiditas sebesar 9,71 kali tingkat likuiditas, nilai maximum dari profitabilitas sebesar 19,68 persen. Untuk nilai ratarata (mean) tingkat likuiditas adalah sebesar 4,4814 dan profitabilitas sebesar 7,8806. Untuk nilai standar deviasi tingkat likuiditas adalah sebesar 2,08780 dan profitabilitas adalah sebesar 4,64412. Uji normalitas yang digunakan dengan normalitas yaitu metode One Sample Kolmogorov Smirnov dapat diketahui bahwa nilai signifikansi untuk data tingkat likuiditas 0,200 dan profitabilitas sebesar 0,080 karena nilai lebih dari 0,05 jadi kesimpulannya data tingkat likuiditas dan profitabilitas terdistribusi normal.

Hasil penelitian ini ternyata tidak sejalan dengan penelitian-penelitian terdahulu yang juga membahas judul yang sama, yang mana peneliti terdahulu memperoleh hasil dengan menyatakan bahwa terdapat pengaruh antara tingkat likuiditas dengan profitabilitas, diantaranya:

Berdasarkan penelitian yang dilakukan oleh Hasmita dengan judul: Analisis Pengaruh Tingkat Likuiditas Terhadap Profitabilitas Pada PT Indosat Tbk Periode 2005-2014, menyatakan bahwa terdapat pengaruh yang signifikan antara tingkat likuiditas terhadap profitabilitas pada PT Indosat Tbk.

Penelitian yang dilakukan oleh Maimunah Harahap dengan judul: Pengaruh Rasio Likuiditas dan Profitabilitas Terhadap Laba Perusahaan PT Siantar Top Tbk Periode 20082015, menyatakan bahwa ada pengaruh secara simultan current ratio (CR), quick ratio (QR) terhadap laba usaha yang signifikan. 
Dari hasil penelitian ini, dapat disimpulkan bahwa tingkat likuiditas tidak memiliki pengaruh terhadap profitabilitas pada PT Media Nusantara Citra Tbk periode 2009-2017.

\section{KESIMPULAN}

Berdasarkan hasil penelitian yang dilakukan pada PT Media Nusantara Citra Tbk dengan judul penelitian “ Analisis Pengaruh Tingkat Likuiditas Terhadap Profitabilitas Pada PT Media Nusantara Citra Tbk Periode 2009-2017" maka dapat ditarik kesimpulan bahwa tidak terdapat pengaruh antara tingkat lukuiditas terhadap profitabilitas. Hal ini dapat diketahui dari: Nilai signifikansi data tersebut adalah sebesar 0,467. Untuk menentukan data tersebut diterima (Ha) dan ditolak (Ho), maka nilai signifikansi harus lebih kecil dari 0,05. Sementara hasil yang diperoleh adalah 0,467 > 0,05. Dengan demikian dapat diambil kesimpulan bahwa data tersebut ditolak (Ho) artinya tidak terdapat pengaruh antara kedua variabel.

\section{DAFTAR PUSTAKA}

Abdul Hamid, Metodologi Penelitian, Bandung: CV Alfabeta, 2012.

Alex S. Nitisemito, Pembelanjaan Perusahaan, Jakarta: Balai Aksara Saadya, 1983.

Asmadi Alsa, Penelitian Kuantitatif dan Kualitatif serta Kombinasinya dalam Penelitian Pisikologi, Yogyakarta, Pustaka Pelajar, 2004.

Annual Report PT Media Nusantara Citra Tbk Tahun 2016.

Bambang Riyanto, Dasar-dasar Pembelanjaan Perusahaan, Yogyakarta: Penerbit GPFE, 2008.

Departemen Agama RI, Al-Alim Al-Qur'an dan Terjemahannya Edisi Ilmu Pengetahuan, Bandung: Al-Mizan Publishing House, 2011.

Dewi Utari, dkk. Manajemen Keuangan: Edisi Revisi, Jakarta: Mitra Wacana Media, 2014.

Getut Pramesti, Statistika Lengkap secara Teori dan Aplikasi dengan SPSS 23, Jakarta: PT Elex Media Komputindo, 2016.

Harmono, Manajemen Keuangan: Berbasis Balanced Scorecard, Jakarta: Bumi Aksara, 2014.

Hasibuan, Abdul Nasser, Effects of Auditor Quality on Market-besed and Accounting-based Financial Statement Quality and Its Impacts on Economic Consequences (A Case Indonesian Capital Market), Internasional Journal of Economic Research No.14 (2017).

Hery, Analisis Laporan Keuangan Yogyakarta: Tri Admojo-CAPS, 2015.

Ibnu Hajar, Dasar-Dasar Metodologi Penelitian Kuantitatif Dalam Pendidikan, Jakarta: PT. RajaGrafindo Persada, 1999. 
Irham Fahmi, Analisis Investasi Dalam Persepektif Ekonomi Dan Politik, Bandung: Penerbit Refika Aditama, 2011.

J. Fred Weston, Manajemen Keuangan, Jilid 2. Edisi Kesembilan, Jakarta: Binarupa Aksara, 1997.

Kasmir \& Jakpar, Studi Kelayakan Bisnis, edisi 2 cetakan keenam, Jakarta: Kencana, 2009.

Kasmir, Analisis Laporan Keuangan, Jakarta: Rajawali Pers, 2013.

K. Fred Skousen. Dkk, Akuntansi Keuangan: Konsep dan Aplikasi, Jakarta: Salemba Empat, 2001.

Lukas Setia Atmajaya, Manajemen KeuanganEdisi Revisi,Yogyakarta: Andi, 2003.

Modul SPSS Versi 23.

Muda, Iskandar dan Abdul Nasser Hasibuan, Public Discovery of The Concept of Money with Value of Time Emerald Reach Proceeding Series (Proceeding of MICoMS 2017), Vol 1 pp.255-261

Putri Pratama dan Jaharuddin, "Rekonstruksi Konsep Profitabilitas Dalam Perspektif Islam," dalam Jurnal Kraith-Humaniora, Volume 2, No. 2, Maret 2018.

Punaji Setyosari, Metode Penelitian, Jakarta: Kencana Prenada Media Group, 2012.

R. Agus Sartono, Manajemen Keuangan Teori dan Aplikasi Edisi 4, Yogyakarta: BPFE, 2010.

Situmorang, Benyamin,Penelitian Pendidikan Konsep Dan Implikasi, Medan: UNIMED PRESS, 2013.

Saifuddin, Metode Penelitian, Yogyakarta: Pustaka Pelajar, 2004.

Sugiyono, Metode Penelitian Bisnis, Bandung: Alfabeta, 2012.

Sukardi, Metodologi Penelitian Pendidikan, Jakarta: PT Bumi Aksara, 2003.

Sumadi Suryabrata, Metodologi Penelitian, Jakarta: PT. RajaGrafindo Persada, 1998.

Suharsimi Arikunto, Produser Penelitian: Suatu Pendekatan Praktek, Edisi Revisi VI, Jakarta: Rineka Cipta, 2006.

Sugiyono, Statistika Untuk Penelitian, Bandung: Alfabeta, 2006.

Sugiono dan Agus Susanto, Cara Mudah Belajar SPSS dan Lisrel Teori dan AplikasiUntuk Analisis Data Penelitian, Bandung: Alfabeta, 2015.

S.Munawir, Analisa Laporan Keuangan, Liberty Yogyakarta: Yogyakarta, 2007.

Syamsuddin, Manajemen Keuangan Perusahaan: Konsep Aplikasi dalam Perencanaan, Pengawasan dan Pengambilan Keputusan. Edisi Baru, Jakarta:PT Raja Grafindo Persada, 2002. 
Syofyan Syafri, Analisis Kritis atas Laporan Keuangan, Jakarta: Rajawali Pers, 2010.

Siregar, Syofyan,Metode Penelitian Kuantitatif: Dilengkapi dengan Perbandingan Perhitungan Manual \& SPSS, Cetakan ke-1 (Jakarta: Kencana Prenada Media Group.

Tanjung, Hendri dan Abrista Devi, Metode Penelitian Ekonomi Islam, Jakarta: Gramata Publishing, 2013.

https://www.dictio.id/t/apa-kelebihan-dan-kelemahan-return-on-investment-roi/12875, diakses 26 Maret 2018 pukul 12.29 WIB. 